\title{
KAJIAN AKTIVITAS INFEKSI Rhizobium sp. INDIGENUS PADA KERANDANG (Pueraria phaseoloides)
}

\author{
The Study on Infection Activity of Indigenous Rhizobium sp. on Kudzu (Pueraria phaseoloides)
}

Nike-Triwahyuningsih, Eko Cahyo Pristiwantoro, Lilik Utari

Program Studi Agronomi Fakultas Pertanian Universitas Muhammadiyah Yogyakarta

\begin{abstract}
Kudzu, a kind of legume cover crops (LCC), plays important roles in soil and water conservation. It is effective for inhibiting erotion, compaction and leaching of nutrients, as well as to suppress weeds. Plants growing with legume ground covers usually show better nutrition, growth and yield. Recently, this cover crops have been widely used to prevent the negative effects and to improve soil physical and nutritional characteristics.

As a legume, bacterial inoculation is to enhance the infection and nodulation activity. A research to observe the role of indigenous Rhizobium on infection and nodulation activity of kudzu was carried out in September till December 2004. The research was done in Regosol volcanic soil in Tlatar Village of Sawangan in Magelang district of Central Java.

A pot experiment was arranged in $4 \times 2$ factorial completely randomized design which was repeated three times. The seedling innoculation with root nodules endophytic bacteria was to increase nodulation and to enhance Kudzu plant growth. The seedlings were inoculated with 1,2 and $3 \mathrm{ml} /$ pot of grinded root nodules of wild plants containing endophytic Rhizobium sp. The wild kudzu plants were taken from coastal sandy land of southern Yogyakarta. All treated seedlings were planted in a sterilized medium to be compared to the unsterilized one in order to examine the role of indigenous bacterias. Observation on bacterial infection activity, nodulation, and plant growth were taken at week $4,6,8$, and 10 . All the datas were variance analyzed and the treatments average were tested with $5 \%$ level of Duncan's multiple range test.

The results showed that application of $2 \mathrm{ml} /$ pot of innoculum significantly increased the infection activity, nodulation and plant growth. Sterilized soil decreased the infection activity. Since the innoculation of endophytic Rhizobium sp. in unsterilized soil significantly increased the infection actifity, nodulation and plant growth, so the indigenous Rhizobium sp. in rhizhosfer was needed to sinergisticaly worked well with inoculum to increase infection activities and root nodulation.
\end{abstract}

Keywords : indigenous Rhizobium, endophytic bacterial inoculation, Kudzu plants

\section{PENDAHULUAN}

Kerandang (Pueraria phaseoloides) atau Kudzu, anggota famili Fabaceae (Leguminosae), merupakan tanaman penutup tanah dan biasa digunakan pada perkebunan kopi, kelapa sawit, jeruk dan tanaman karet. Keuntungan adanya tanaman penutup tanah (cover crop) adalah dapat mengurangi penggunaan herbisida, melindungi top soil dari erosi karena angin atau air, penggembur tanah, menambah bahan organik tanah, menambah mikroorganisme tanah, meningkatkan ketersediaan Nitrogen, meningkatkan kelembaban tanah, memobilisasi mineral tanah dan membawanya ke top soil, meningkatkan kandungan air dan sirkulasi udara tanah. Oleh karena kemampuannya itu maka cover crop banyak dimanfaatkan dalam konservasi lahan-lahan kritis (Anonim, 2004).

Pueraria phaseoloides merupakan legum merambat (climbing legum) yang mempunyai pertumbuhan sangat cepat dengan panjang dapat mencapai 8-9 meter. Tanaman ini memiliki sistem perakaran dalam yang dapat membantu mencegah erosi tanah. Pertumbuhan tanaman yang cepat juga membantu mencegah run-off penyebab longsor. Tanaman ini dapat beradaptasi pada iklim kering atau basah dan mampu tumbuh pada keadaan tanah masam atau basa (Anonim, 2004). Batang kerandang mempunyai serat kuat yang dapat digunakan sebagai tali. Daun, biji dan bunga kerandang dapat dimanfaatkan sebagai sayuran dan bahan makanan lain. Akibat 
pemanfaatan yang sangat intensif, kini kerandang hampir punah karena masyarakat belum berhasil mengkonservasi.

Keberhasilan penanaman kerandang dapat ditingkatkan dengan memberikan inokulum Rhizobium sp. Rhizobium merupakan bakteri pembentuk nodul akar pada legum. Keuntungan adanya bakteri Rhizobium pada akar tanaman adalah membantu pengikatan nitrogen udara. Pada tanah-tanah yang miskin hara nitrogen, keberadaan bakteri ini menjadi sangat penting, terutama karena dapat menyediakan sumber senyawa nitrogen bagi tanaman. Inokulasi Rhizobium pada legum dapat dilakukan dalam beberapa bentuk antara lain : (1) tanah risosfer bekas tanaman legum, (2) Rhizobium endofitik akar tanaman legum, atau (3) inokulum biakan murni. Pemberian berbagai jumlah inokulum tersebut biasanya dilakukan bersamaan dengan penanaman biji.

\section{METODE PENELITIAN}

Penelitian dilaksanakan di Dusun Tlatar, Desa Krogowanan, Kecamatan Sawangan, Kabupaten Magelang, Propinsi Jawa Tengah, dengan ketinggian tempat $700 \mathrm{~m}$ dpl dan di Laboratorium Kimia Fakultas Pertanian Universitas Muhammadiyah Yogyakarta. Penelitian dilaksanakan pada bulan September sampai Desember 2004.

Bahan-bahan yang digunakan adalah: (1) tanah Regosol Vulkanik dari Sawangan, Magelang sebagai media tanam, (2) nodul akar kerandang liar dari pantai Kulon Progo sebagai sumber inokulum bakteri, (3) benih kerandang dari pantai Kulon Progo sebagai bahan tanam, (4) medium YMA (Yeast Manitol Agar) + Congo Red sebagai media pertumbuhan bakteri Rhizobium sp. (5) bahan-bahan lain yang dibutuhkan untuk inokulasi dan penanaman.

Penelitian dilakukan dengan metode percobaan pot yang disusun dalam Rancangan Acak Lengkap (RAL) faktorial $4 \times 2$. Faktor pertama adalah jumlah inokulum yang terdiri atas 4 aras yaitu : tanpa inokulum, inokulasi Rhizobium endofitik $1 \mathrm{ml}, 2 \mathrm{ml}$, dan $3 \mathrm{ml}$ per tanaman. Untuk mengetahui peranan bakteri indigenus, maka faktor kedua adalah membandingkan media steril dan non steril. Dari 8 kombinasi perlakuan tersebut masing-masing diulang 3 kali.

Pengamatan dilakukan terhadap : jumlah nodul akar total, berat total nodul akar $(\mathrm{g})$, persentase nodul efektif $(\%)$, berat segar dan kering akar $(\mathrm{g})$, panjang tanaman $(\mathrm{cm})$, jumlah daun dan jumlah ruas. Data dianalisis dengan sidik ragam pada taraf beda $5 \%$, bila ada beda dilakukan uji DMRT pada taraf $5 \%$.

\section{HASIL DAN PEMBAHASAN}

\section{Pengaruh Perlakuan Terhadap Aktifitas Infeksi Rhizobium sp. dan Nodulasi}

a. Jumlah nodul akar total

Tidak ada interaksi antara perlakuan inokulasi dan sterilisasi media terhadap pertumbuhan jumlah nodul. Inokulasi dengan bakteri endofitik berhasil meningkatkan jumlah nodul akar. Pertumbuhan jumlah nodul pada semua perlakuan inokulasi hampir sama pada tiap minggu pengamatan (gambar 1a), kecuali pada perlakuan tanpa inokulasi. Peningkatan jumlah nodul hingga minggu ke 10 pada perlakuan inokulasi 2 $\mathrm{ml}$ per tanaman relatif paling tinggi.

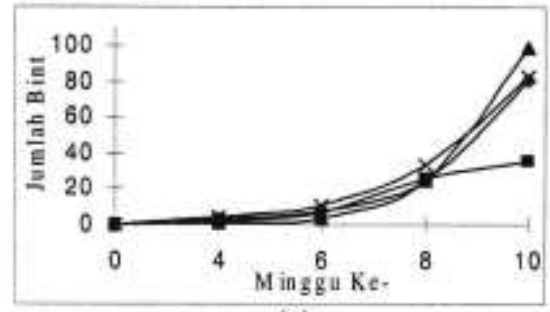

(a)

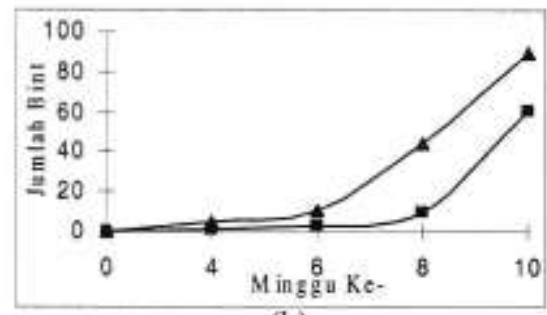

(b)

Gambar 1. Perkembangan jumlah nodul total pada perlakuan (a) macam inokulum, (b) sterilisasi media

Reterangan: (a) * tarpa inokdim, 4 inokulam 1 miltanaman, $\mathbf{\Lambda}$ inckulam 2 mitanaman, $\mathrm{X}$ : inokubm 3 mitaniman, (b) $\approx$ media stenl, $\boldsymbol{\Lambda}$ mecia non stenl.

Pada perlakuan sterilisasi media, peningkatan jumlah nodul akar pada media non steril sudah dimulai pada minggu ke 6 dan terus meningkat hingga akhir pengamatan. Sedangkan pada tanah steril peningkatan jumlah total nodul akar, baru mulai minggu ke 8 . Hal ini kemungkinan karena pada tanah non steril terdapat bakteri indigenus yang kompatibel dengan bakteri inokulum dan ikut membantu pembentukan nodul akar.

\section{b. Berat segar nodul akar $(\mathrm{g})$}

Berat segar nodul total merupakan cerminan dari ukuran nodul akar yang terbentuk. Semakin banyak dan besar ukuran nodul akar, beratnya akan semakin besar. Sebagaimana pada jumlah nodul, tidak ada interaksi antara perlakuan inokulasi dan sterilisasi media terhadap pertumbuhan berat nodul. 
Pertumbuhan berat nodul pada semua perlakuan adalah hampir sama hingga minggu ke 6 (Gambar 2a dan 2b). Pada pengamatan minggu ke 8 , terjadi peningkatan pertumbuhan berat nodul akar pada semua perlakuan inokulasi kecuali pada perlakuan tanpa inokulasi yang justru menurun. Perlakuan inokulasi 2 ml per tanaman memberikan berat nodul relatif tertinggi daripada perlakuan lain.

Sterilisasi media secara nyata menekan pertumbuhan nodul. Ini terlihat pada pengamatan mulai minggu ke 6 pertumbuhan nodul akan meningkat cepat pada perlakuan tanpa sterilisasi, tetapi tidak begitu cepat pada media yang disterilisasi. Ini sekali lagi membuktikan bahwa adanya bakteri indigenus dalam tanah dapat bekerja secara sinergistik dengan bakteri endofitik dalam inokulum.

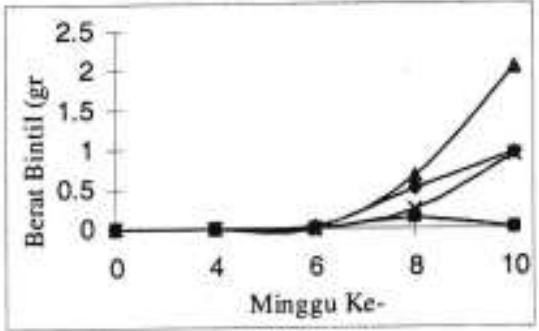

(a)

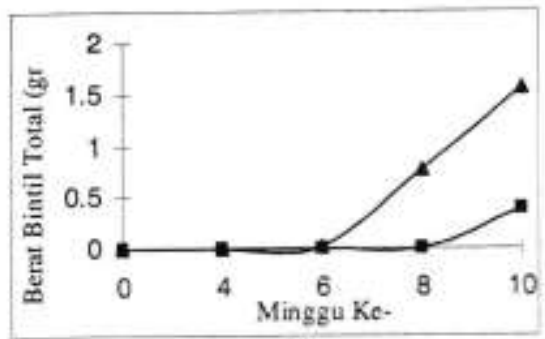

(b)

Gambar 2. Perkembangan berat nodul total pada perlakuan (a) jumlah inokulum, (b) sterilisasi media

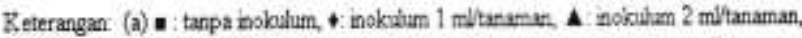
$X$ inokubm 3 miltanaman, (b) a meda sten', $\mathbf{A}$ meds bos stenl.

\section{d. Jumlah nodul akar efektif}

Nodul efektif adalah nodul akar yang dapat mengikat nitrogen udara, yang ditandai oleh warna merah karena adanya leghaemoglobin. Perkembangan jumlah nodul akar efektif dapat dilihat pada gambar 3 yang memperlihatkan peningkatan jumlah nodul efektif. Tidak ada interaksi antara jumlah inokulum dan sterilisasi media terhadap jumlah nodul, kecuali pada pengamatan minggu ke 10 . Peningkatan jumlah nodul akar efektif paling tinggi terjadi pada pemberian inokulum $2 \mathrm{ml}$ per tanaman. Pada perlakuan tanpa sterilisasi media, peningkatan jumlah nodul akar efektif nyata lebih tinggi.
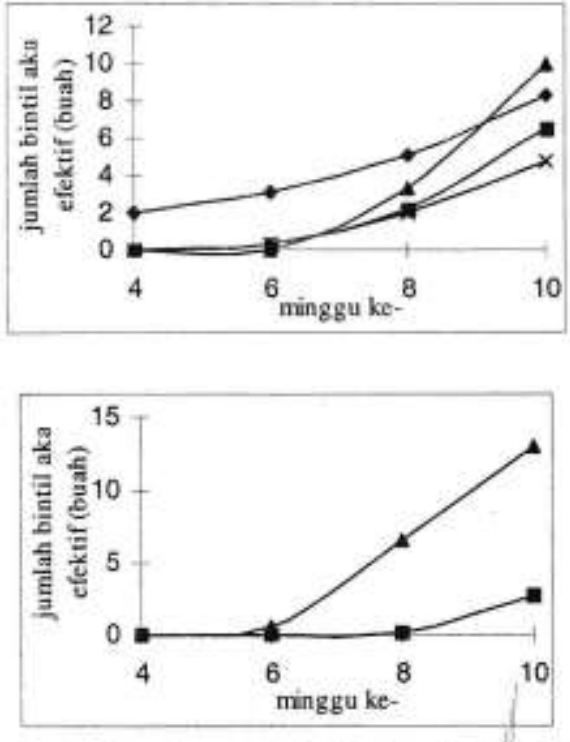

Gambar 3. Perkembangan jumlah nodul efektif pada perlakuan (a) jumlah inokulum, (b) sterilisasi media

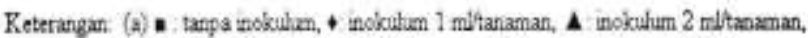
$X$ : nokulum 3 mltanaman, (b) a meda sterl, $\mathbf{A}$ : medas aon sterl

Pada nodul akar yang mengalami penuaan, nodul yang telah melewati masa efektifnya akan mulai mati ditandai dengan hilangnya pigmen leghemoglobin. Pada tanaman yang tidak diinokulasi berat nodul akan cenderung menurun, dan jumlah nodul efektif juga berkurang. Menurut Sutedjo et al. (1991), dalam nodulnodul tua yang terdekomposisi, bakteroid yang bentuknya mengembang itu tertekan, sehingga terlihat kecil, oval, bernoda-noda gelap dalam kerumunan. Bakteri ini hanya mampu menginfeksi mulai minggu ke 6 sampai ke 8 dan menurun pada minggu ke 10 . Laju penurunan jumlah bakteroid ini dapat dikurangi dengan inokulasi, dan pemberian inokulum $2 \mathrm{ml}$ per tanaman memberikan peningkatan yang relatif paling tinggi. Interaksi antara perlakuan inokulasi dengan sterilisasi media terhadap jumlah nodul efektif ditemukan pada minggu ke 10 . Inokulasi 1-2 ml per tanaman pada media yang tidak disterilisasi nyata memberikan jumlah nodul efektif tertinggi, seperti terlihat pada tabel 1 .

Tabel 1. Rerata jumlah nodul akar efektif minggu 10

\begin{tabular}{|c|c|c|c|c|c|}
\hline \multirow[b]{2}{*}{$\begin{array}{l}\text { Serilisad } \\
\text { Mria }\end{array}$} & \multicolumn{4}{|c|}{ Putakum lochaias } & \multirow[b]{2}{*}{ Rerta } \\
\hline & $\begin{array}{c}\text { Tapre } \\
\text { Inokulum }\end{array}$ & $\begin{array}{l}\text { Inokatis } \\
\text { I nitan }\end{array}$ & $\begin{array}{l}\text { Inhilasi } \\
2 \text { mitan }\end{array}$ & $\begin{array}{l}\text { Indulaki } \\
3 \text { miltan }\end{array}$ & \\
\hline $\begin{array}{c}\text { Sectil } \\
\text { Nan Sicill }\end{array}$ & $\begin{array}{c}265 \mathrm{c} \\
1246 \mathrm{~b}\end{array}$ & $\begin{array}{l}342 \mathrm{c} \\
1750 \mathrm{a}\end{array}$ & $\begin{array}{l}299 \mathrm{c} \\
1898 \mathrm{a}\end{array}$ & $\begin{array}{l}565 \mathrm{bc} \\
598 \mathrm{bc}\end{array}$ & $\begin{array}{l}3.88 \\
1373\end{array}$ \\
\hline Reris: & 7.56 & 1046 & 1099 & 5.81 & $(+)$ \\
\hline
\end{tabular}

Keterangan : Angka dengan huruf sama berarti tidak berbeda nyata pada uji jarak berganda Duncan taraf $5 \%$ 
Nike-Triwahyuningsih et al.

\section{c. Persentase nodul efektif (\%)}

Persentase nodul akar efektif menunjukkan proporsi jumlah nodul efektif terhadap total nodul yang terbentuk dalam akar. Semua perlakuan inokulasi atau sterilisasi media memperlihatkan perkembangan proporsi nodul efektif yang hampir sama, yaitu meningkat pada minggu ke $6-8$ dan selanjutnya mulai menurun hingga minggu ke 10 (gambar $4 a$ dan $4 b$ ).

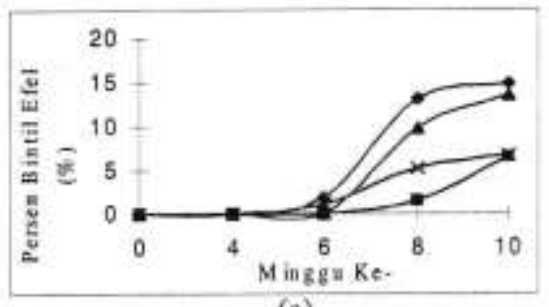

(a)

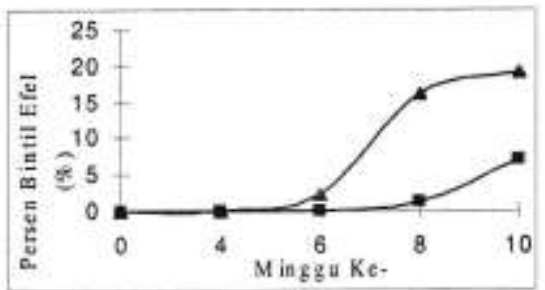

(b)

Gambar 4. Perkembangan persentase nodul efektif (\%) pada perlakuan (a) jumlah inokulum, (b) sterilisasi media

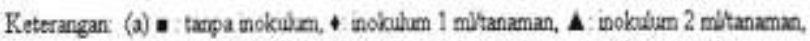
$X$ inobulum 3 mitanaman, (b) $\bullet$ meda stenl, $\Delta$ media noc steri

Waktu pembentukan nodul sangat bervariasi diantara spesies. Fiksasi $\mathrm{N}_{2}$ umumnya dimulai 25-35 hari setelah tanam, dan ada perbedaan tingkat aktivitas nitrogenase diantara spesies. Antara infeksi dan mulainya kegiatan fiksasi dapat berlangsung 3 hingga 5 minggu (Nike-Triwahyuningsih, 1994). Pada perlakuan inokulasi, peningkatan persentase nodul efektif yang cepat terjadi antara minggu ke 6 dan ke 8, kecuali pada perlakuan tanpa inokulum yang meningkat cepat baru mulai minggu ke 8 . Pemberian inokulum secara nyata mampu meningkatkan infeksi dan nodulasi, sehingga aktivitas bakteri juga lebih cepat.

Sterilisasi media secara nyata menekan persentase nodul efektif. Mulai minggu ke 8 terjadi peningkatan persentase nodul efektif yang tinggi pada perlakuan tanpa sterilisasi. Pada media steril peningkatan baru di mulai pada minggu ke 8 , itupun tidak sebesar peningkatannya pada perlakuan tanpa sterilisasi. Hal ini menunjukkan kompatibilitas antara bakteri Rhizobium sp indigenus yang ada pada media non steril dengan bakteri endofitik inokulum dapat membantu meningkatkan nodulasi dan aktivitas infeksi, sehingga pembentukan nodul makin cepat dan jumlah nodul efektif makin banyak. Keadaannya akan berbeda pada media steril, bakteri penginfeksi akar hanya berasal dari inokulum saja sehingga proses pembentukan nodul lebih lambat dan jumlah nodul yang terbentuk juga lebih sedikit.

\section{Pengaruh Perlakuan Terhadap Pertumbuhan Tanaman}

Hasil fiksasi Nitrogen oleh bakteri akan dimanfaatkan untuk menyusun asam amino, protein dan senyawa $\mathrm{N}$ organik penting lainnya yang digunakan selama masa pertumbuhan tanaman. Selama masa pertumbuhan tanaman menghasilkan biomassa yang digunakan untuk membentuk bagian-bagian tubuh. Perubahan akumulasi biomassa akan terjadi seiring dengan umur tanaman, dan merupakan indikator pertumbuhan tanaman. Biomassa tanaman meliputi semua bahan tanaman yang berasal dari hasil fotosintesis, seperti tercermin dari parameter berikut.

\section{a. Berat segar akar (g)}

Pertumbuhan berat segar akar dapat dilihat pada gambar $5 \mathrm{a}$ dan $5 \mathrm{~b}$ berikut.

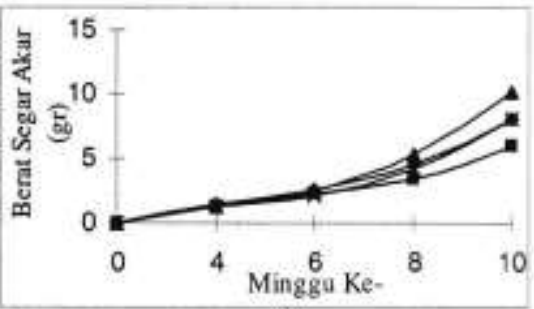

(a)

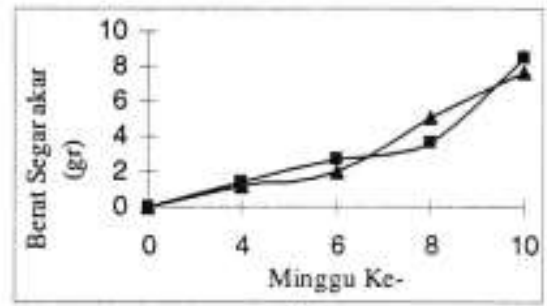

(b)

Gambar 5. Pertumbuhan berat segar akar (g) pada perlakuan (a) jumlah inokulum, (b) sterilisasi media

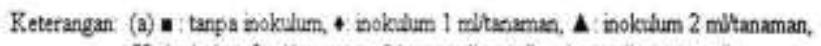

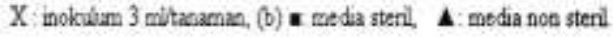

Gambar 5 menunjukkan bahwa berat segar akar pada semua perlakuan inokulasi dan sterilisasi media meningkat hingga minggu ke 10 dengan peningkatan yang relatif sama. Pada minggu ke10, pemberian inokulum $2 \mathrm{ml} /$ tanaman memberikan berat 
segar akar relatif lebih tinggi daripada perlakuan inokulasi yang lain.

Tabel 2. Rerata berat segar akar minggu ke $10(\mathrm{~g})$

\begin{tabular}{|c|c|c|c|c|c|}
\hline \multirow[b]{2}{*}{$\begin{array}{l}\text { Sterilisasi } \\
\text { Media }\end{array}$} & \multicolumn{4}{|c|}{ Perlakuan Inokulasi } & \multirow[b]{2}{*}{ Rerata } \\
\hline & $\begin{array}{c}\text { Tanpa } \\
\text { Inokulum }\end{array}$ & $\begin{array}{l}\text { Inokulasi } \\
1 \text { ml/an }\end{array}$ & $\begin{array}{c}\text { Inokulasi } \\
2 \mathrm{~m} / \mathrm{tan}\end{array}$ & $\begin{array}{l}\text { Inokulasi } \\
3 \text { mi/tan }\end{array}$ & \\
\hline Sieril & $5.20 c$ & $10.19 \mathrm{ab}$ & $7.17 \mathrm{bc}$ & $11.53 \mathrm{a}$ & 8,53 \\
\hline Non Steril & 6.78 be & $5.82 \mathrm{bc}$ & $13.50 \mathrm{a}$ & $4.76 \mathrm{c}$ & 7,72 \\
\hline Rerata & 5,99 & 8.01 & 10.34 & 8.15 & $(+)$ \\
\hline
\end{tabular}

Keterangan : Angka dengan huruf sama berarti tidak berbeda nyata pada uji jarak berganda Duncan taraf $5 \%$

Pada minggu ke 10 ada interaksi antara perlakuan inokulasi dan sterilisasi media terhadap berat segar akar (tabel 2). Pemberian inokulum $2 \mathrm{ml} /$ tanaman memberikan segar akar terbesar dibanding perlakuan inokulasi yang lain. Pada tanah non steril, inokulasi 2 $\mathrm{ml} /$ tanaman memberikan berat segar akar terbesar. Penambahan inokulum menjadi $3 \mathrm{ml} /$ tanaman pada tanah steril dapat memberikan berat segar akar sama.

\section{b. Berat kering akar (g)}

Pertumbuhan berat kering akar pada perlakuan inokulasi dan sterilisasi media dapat dilihat pada gambar $6 \mathrm{a}$ dan $6 \mathrm{~b}$ berikut.

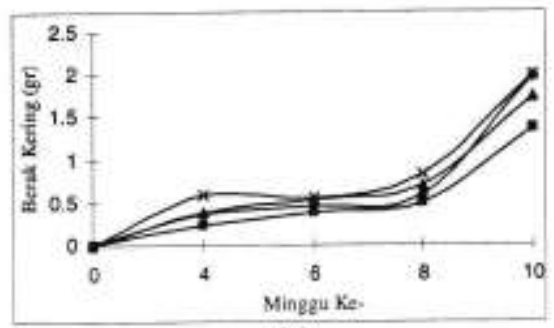

(a)

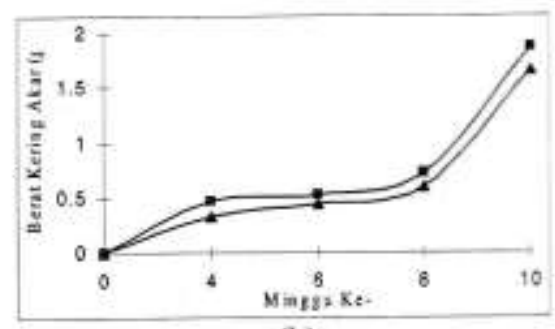

(b)

Gambar 6. Pertumbuhan berat kering akar (g) pada perlakuan (a) jumlah inokulum, (b) sterilisasi media

Keterangan (a) - tarpa inokubm, + inokubm 1 mitanamah, $\mathbf{A}$ : nokutum 2 mittanaman, $\mathrm{X}$ : inokculm 3 mitanaman, (b) = media steril, $\mathbf{A}$ media noc sterl

Gambar 6 menunjukkan bahwa berat kering akar mengalami perkembangan dengan pola yang relatif sama pada semua perlakuan. Umumnya peningkatan sangat tajam dimulai pada minggu ke 8 , setelah mengalami fase stasioner pada minggu ke 4 hingga ke 6 . Pola ini khas untuk tanaman perrennial. Peningkatan jumlah dan proporsi nodul efektif hingga pengamatan minggu ke 10 tampaknya diikuti oleh peningkatan pertumbuhan akar.

\section{c. Panjang tanaman (cm)}

Pertumbuhan panjang tanaman pada perlakuan inokulasi dan sterilisasi media dapat dilihat pada gambar $7 \mathrm{a}$ dan $7 \mathrm{~b}$ berikut.

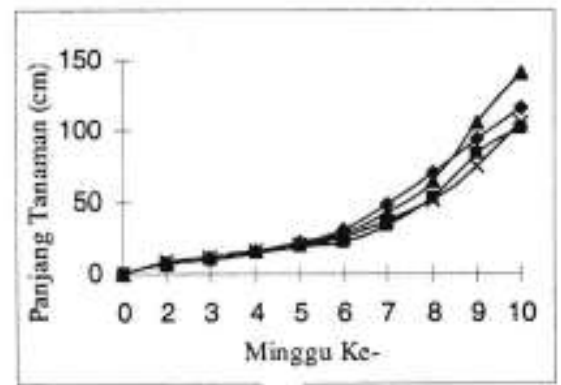

(a)

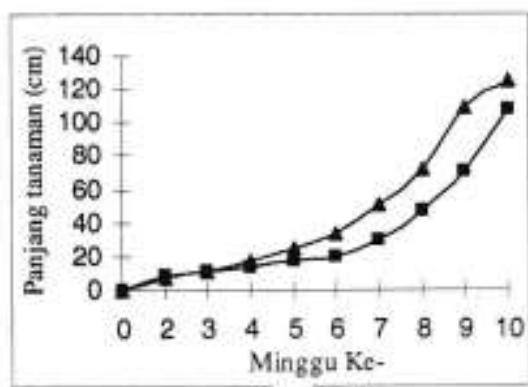

(b)

Gambar 7. Pertumbuhan panjang tanaman pada perlakuan (a) jumlah inokulum, (b) sterilisasi media

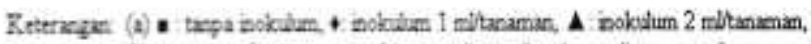

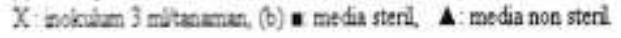

Gambar 7 memperlihatkan pola pertumbuhan panjang tanaman yang relatif sama pada semua perlakuan inokulasi dan sterilisasi media. Pada perlakuan inokulasi, pemberian inokulum sebanyak 2 $\mathrm{ml} /$ tanaman memberikan panjang tanaman yang lebih tinggi daripada perlakuan inokulasi yang lain (7a). Perlakuan sterilisasi media dapat menekan pertumbuhan panjang tanaman (7b).

Pada minggu ke 10, ditemukan adanya interaksi antara perlakuan inokulasi dan sterilisasi media terhadap panjang tanaman (tabel 3). Inokulasi 1 - $2 \mathrm{ml} /$ tanaman pada tanah non steril memberikan panjang tanaman yang nyata lebih tinggi daripada perlakuan lain. Pada tanah steril, peningkatan panjang tanaman dapat dilakukan dengan penambahan inokulum 
hingga $3 \mathrm{ml} /$ tanaman . Kondisi ini membuktikan bahwa keberadaan Rhizobium indigenus sangat diperlukan bagi pertumbuhan tanaman.

Tabel 3. Rerata panjang tanaman pada minggu ke 10 (cm)

\begin{tabular}{|c|c|c|c|c|c|}
\hline \multirow[b]{2}{*}{$\begin{array}{l}\text { Serilisasi } \\
\text { Modia }\end{array}$} & \multicolumn{4}{|c|}{ Prtakuan Irokulasi } & \multirow[b]{2}{*}{ Rerata } \\
\hline & $\begin{array}{c}\text { Tarpo } \\
\text { Inokulum }\end{array}$ & $\begin{array}{l}\text { Inokulasi } \\
1 \mathrm{mithan}\end{array}$ & $\begin{array}{l}\text { Inckulas } \\
2 \text { mitan }\end{array}$ & $\begin{array}{l}\text { Inckailasi } \\
3 \mathrm{~m} / \mathrm{tan}\end{array}$ & \\
\hline Steril & $95.8 \mathrm{bc}$ & $8939 \mathrm{c}$ & $116.67 \mathrm{bc}$ & 127 abc & 107,34 \\
\hline Non Steril & 10645 be & $141.11 \mathrm{ab}$ & $166.78 \mathrm{a}$ & $84.33 c$ & 124,67 \\
\hline Renala & 101,17 & 115,45 & 141,73 & 105.67 & $(+)$ \\
\hline
\end{tabular}

Keterangan : Angka dengan huruf sama berarti tidak berbeda nyata pada uji jarak berganda Duncan taraf $5 \%$

\section{d. Jumlah daun}

Pengamatan jumlah daun dilakukan pada tanaman sampel dengan menghitung jumlah daun yang terbentuk dengan syarat daun telah membuka penuh. Perkembangan jumlah daun pada perlakuan inokulasi dan sterilisasi media pada pengamatan minggu ke 2, 3 . $4,5,6,7,8,9$ dan 10 dapat dilihat pada gambar 8 .

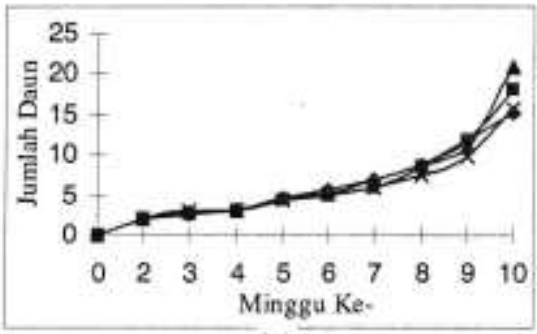

(a)

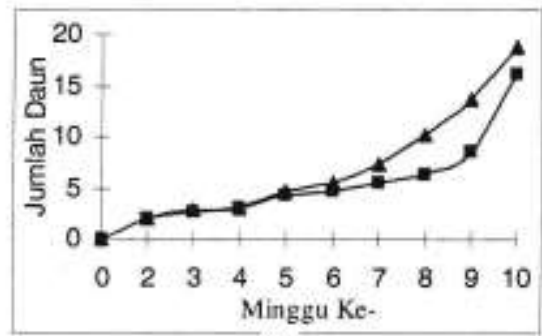

(b)

Gambar 8. Pertumbuhan jumlah daun pada perlakuan

(a) jumlah inokulum, (b) sterilisasi media

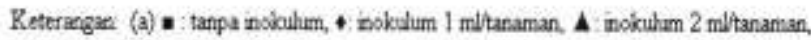
$\mathrm{X}$ inokdum 3 mitanaman, (b) meda sterl, $\boldsymbol{\Lambda}$ : meda bon ateril.

Gambar 8 menunjukkan bahwa peningkatan jumlah daun pada perlakuan inokulasi hingga minggu ke 9 relatif sama, dan berbeda pada minggu ke 10 (tabel 4). Pada minggu ke 10 perlakuan inokulasi Rhizobium sebanyak $2 \mathrm{ml} /$ tanaman memberikan jumlah daun yang tertinggi, meskipun relatif tidak berbeda dengan perlakuan inokulasi $3 \mathrm{ml} /$ tanaman dan tanpa inokulasi.
Pada perlakuan sterilisasi media dari minggu ke 2 hingga minggu ke 6 memberikan peningkatan jumlah daun yang relatif sama, namun berubah mulai minggu ke 7 hingga akhir pengamatan. Jumlah daun pada media non steril relatif lebih tinggi dibandingkan jumlah daun pada media steril.

Tabel 4. Rerata berat kering akar (g), jumlah daun dan jumlah ruas pada minggu ke 10

\begin{tabular}{|c|c|c|c|}
\hline Perlakuan Inokulasi & $\begin{array}{c}\text { berat } \\
\text { kering } \\
\text { akar }(\mathrm{g})\end{array}$ & $\begin{array}{c}\text { jumlah } \\
\text { daun } \\
\text { (buah) }\end{array}$ & $\begin{array}{c}\text { jumlah ruas } \\
\text { (buah) }\end{array}$ \\
\hline Tanpa inokulum & $1.35 \mathrm{a}$ & $18.16 \mathrm{ab}$ & $26.78 \mathrm{a}$ \\
Inokulum $1 \mathrm{ml}$ & $2.03 \mathrm{a}$ & $15.11 \mathrm{~b}$ & $26.72 \mathrm{a}$ \\
Inokulum $2 \mathrm{ml}$ & $1.67 \mathrm{a}$ & $20.78 \mathrm{a}$ & $26.33 \mathrm{a}$ \\
Inokulum $3 \mathrm{ml}$ & $1.99 \mathrm{a}$ & $15.66 \mathrm{ab}$ & $22.05 \mathrm{a}$ \\
\hline Sterilisusi media & & & \\
\hline Steril & $1.86 \mathrm{p}$ & $16.13 \mathrm{p}$ & $25.16 \mathrm{p}$ \\
Non Steril & $1.66 \mathrm{p}$ & $18.72 \mathrm{p}$ & $25.78 \mathrm{p}$ \\
\hline
\end{tabular}

Keterangan : Angka pada kolom sama yang diikuti dengan huruf sama berarti tidak berbeda nyata pada uji jarak berganda Dunean taraf $5 \%$

\section{e. Jumlah Ruas}

Pengamatan jumlah ruas dilakukan dengan menghitung jumlah ruas yang terbentuk setiap minggu. Pertumbuhan jumlah ruas pada pengamatan minggu ke $2,3,4,5,6,7,8,9$ dan 10 dapat dilihat pada gambar 9 berikut ini.

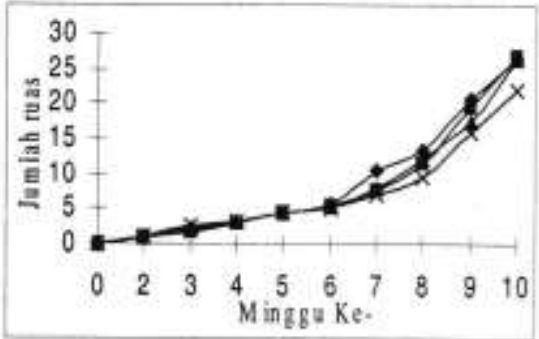

(a)

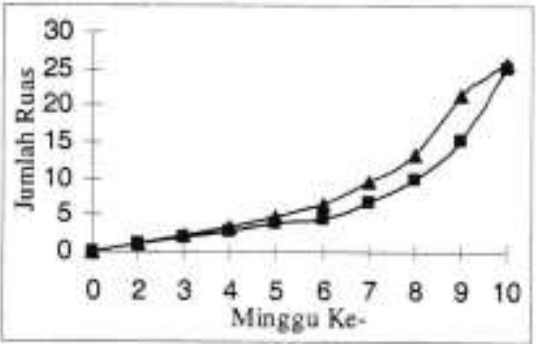

(b)

Gambar 9. Pertumbuhan jumlah ruas berdasarkan perlakuan (a) jumlah inokulum, (b) sterilisasi media

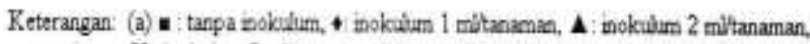
$X$ : inokuim 3 mitronaman, (b) a medis steril, $\mathbf{A}$ : media noe steril 
Dari gambar 9 diketahui bahwa peningkatan jumlah ruas pada semua perlakuan inokulasi hingga minggu ke 6 relatif sama dan berubah mulai minggu ke 7 hingga akhir pengamatan. Pada perlakuan sterilisasi media hingga minggu ke 5 , peningkatan jumlah ruas relatif sama namun berubah mulai minggu ke 6 hingga ke 9. Perlakuan pada media nonsteril memberikan jumlah ruas lebih tinggi dibanding perlakuan pada media steril. Pada minggu ke 10 , perlakuan inokulasi dan sterilisasi media memberikan jumlah ruas yang relatif sama (tabel 4).

\section{A. Kesimpulan}

1. Inokulasi bibit dengan Rhizobium endofitik nodul akar tanaman liar sebanyak $2 \mathrm{ml} /$ pot secara nyata memacu aktivitas infeksi, meningkatkan nodulasi, dan memperbaiki pertumbuhan tanaman.

3. Karena sterilisasi tanah medium dapat menekan aktivitas infeksi, ini berarti keberadaan Rhizobium indigenus rhizosfer diperlukan karena dapat bekerja secara sinergis dengan inokulum untuk memacu infeksi dan nodulasi.

4. Inokulasi Rhizobium endofitik pada tanah non steril nyata dapat meningkatkan aktivitas infeksi, nodulasi dan pertumbuhan tanaman.

\section{B. Saran}

Merujuk hasil penelitian yang membuktikan bahwa peranan bakteri indigenus cukup besar, maka pemberian inokulum dapat langsung diberikan pada daerah perakaran kerandang.

\section{DAFTAR PUSTAKA}

Anonim, 2004. "Leguminosae - Pueraria phaseoloides". http://www.echonet.org.

Elkan, G. H, 1987. "Symbiotic Nitrogen Fixation Technology”. Departemen of Microbiology North Carolina State University Raliegh, North Carolina.

Gunarto L, Farid A dan Taslim H.1987. "Pengaruh Pemberian $\mathrm{N}$ dan Inokulasi Rhizobium Terahadap Penodulan Akar Serta Hasil Tanaman Kedelai dan Kacang Hijau".Agrika,, Vol 2.No 1. hal 33-37.

Nike-Triwahyuningsih. 1994. "Mekanisme fiksasi Nitrogen pada legum". Jurnal Agro UMY No.4, tahun II. September 1994. Universitas Muhammadiyah Yogyakarta.

Rao, 1994. "Mikroorganisme Tanah dan Pertumbuhan Tanaman". Universitas Indonesia Press. Jakarta

Sitompul, S. M. dan B. Guritno, 1995. Analisis pertumbuhan tanaman, Gadjah Mada University Press. 412 h 